\title{
Data Quality Control of an Observational Tool to Analyze Football Semiotricity
}

\section{Evaluación de una herramienta observacional del código praxémico del fútbol}

\author{
Avaliação de um instrumento observacional código praxémico futebol
}

\author{
Diego Marqués Jiménez ${ }^{1 *}$ y Raúl Martínez de Santos Gorostiaga ${ }^{2}$ \\ ${ }^{1}$ Máster Actividad Física y Deporte (UPV-EHU), ${ }^{2}$ Universidad del País Vasco/Euskal Herriko Unibertsitatea (UPV-EHU)
}

\begin{abstract}
Resumen: En un reciente estudio se ha sacado a la luz el "código secreto" del fútbol mediante el uso del método observacional. Sin embargo, en esta investigación no se aclaran ciertos aspectos metodológicos, como el protocolo de observación, ni se expone el procedimiento empleado para el control de la calidad del dato. Dado que estas carencias comprometen la fiabilidad de los resultados, se decidió realizar el análisis de la fiabilidad de la herramienta observacional empleada en dicho estudio siguiendo los principios básicos de este método. Tras un estudio minucioso de esta herramienta se diseńó un instrumento de observación mixto con un sistema de formato de campo donde cada criterio es un sistema de categorías, exhaustivo y mutuamente excluyente. Tras el entrenamiento de los observadores, se tomaron datos con los que se estimaron los coeficientes de acuerdo y asociación (frecuencias y porcentajes de acuerdo, coeficientes de correlación, índices de Kappa de Cohen) inter e intraobservadores, realizando posteriormente un análisis de generalizabilidad. Los resultados obtenidos son satisfactorios y nos permiten afirmar que la herramienta es fiable para analizar la semiotricidad del fútbol.
\end{abstract}

Palabras clave: fútbol, semiotricidad, metodología observacional, control de calidad del dato.

Abstract: The "secret code" of the football was found out by a recent study. However, in this research, methodological aspects have not been reported; such as observation protocol or the procedure used to control the data quality. These deficiencies compromise the reliability of the results, so we have decided to analyze the reliability of the observational tool used in this study following the basic principles of this method. After a detailed study of the tool used in this study, an instrument based on a mixed system of field formats and E/ME category systems. After training of observers, data were taken to estimate coefficients and association agreement (frequencies and percentages of agreement, correlation coefficients, Kappa indices Cohen) inter and intraobserver, and after that, make a generalizability analysis. Results are satisfactory, and allow us to say that the tool is reliable to analyze football 's semiotricity.

Keywords: football, semiotricity, observational methodology, data quality control.

Resumo: Em um estudo recente se desvendou o "código secreto" do Futebol a partir do uso do método de observação. No entanto, esta pesquisa carece de determinados aspectos metodológicos, como um protocolo de observação rígido e uma descrição do procedimento utilizado para controlar a qualidade dos dados. Constatando-se que essas deficiências comprometem a fiabilidade dos resultados, optou-se por analisar a fiabilidade do instrumento de observação utilizada neste estudo seguindo os princípios básicos do método observacional. Depois de um estudo detalhado da ferramenta utilizada neste estudo, elaboramos um instrumento de observaçáo com um formato de campo de sistema misto em que cada critério é um sistema de categorias exaustivo e mutuamente exclusivo. Após o treinamento dos observadores, se obtiveram os dados com o objetivo de estimar os coeficientes e acordos de associação (frequências e porcentagens de acordo, coeficientes de correlação e índices Kappa Cohen) inter e intra-observador, para realizar uma posterior análise de generalização. Os resultados são satisfatórios e permitem afirmar que a ferramenta utilizada no estudo anterior é fiável para analisar a semiotricidade no Futebol.

Palavras-chave: futebol, semiotricidad, metodologia observacional, controle da qualidade de dados.

\section{Introduction}

Football association belongs to the same domain as many other team sports and traditional games in which the players must make decisions under severe conditions of social uncertainty. More than 30 years ago, Pierre Parlebas (1990, p. 75) defended the intimate relationship between intelligence and motor behavior and proposed the existence of eight categories of sports situations according to the decision constraints imposed on the players by the game. These eight categories are nowadays considered the basic domains of motor action

\footnotetext{
Dirección para correspondencia [Correspodence address]: Diego Marqués Jiménez. C/ Cortes de Aragón 5 3º. 50500 Tarazona (España). E-mail: diegomarquesjimenez@gmail.com
}

and their existence can be empirically supported through learning transfers research (Parlebas \& Dugas, 1998).

This stochastic component affects the performance of both players and teams in football (Bayer, 1986; Castelo, 1994; Castellano, Hernández-Mendo, Morales-Sánchez \& Anguera, 2007; Gréhaigne, 2001; Konzag 1983; Mombaerts, 2000; Teodorescu, 1984). So football performance depends on communication of the players. Every player's conduct is always communicative (Parlebas, 1976). They cannot decide when to start or finish communicating because all the motor behavior functions as a sign. Consequently, the player must have the ability to "read the game" (to attribute strategic 
meanings of the motor behavior of other players). This competence is related to the so-called semiotricity (semiology of the motricity), the core of the tactical ability (Arana, 2011; Ardá, 1998; Castellano \& Echeazarra, 2013; HernándezMendo, 1996; Lago, 2011; Martínez de Santos, 2008; Perea, 2008; Reina, 2011; Robles, 2012) that allows football players to dominate the uncertainty issued by the situation.

To make this possible, the players must have the ability to understand the tactical meaning of the movements of the other players, both partners and opponents, which is a long and complex process that may require modifications of the game in order to let them develop this competence. Young players have to learn to decipher the praxemes in play. A praxeme, which has the unusual property of being an integral part of an action (Parlebas, 2001), is the semiotic unit of the cognitive and communicative processes that occur in a soccer game. It is the action itself, but with different meanings according to whom is producing it. Praxemes announce the sociomotor subrole ("basic behavioral units of the strategic functioning of game" (Parlebas, 2001, p. 349)). Therefore, players with more ability to decipher praxemes will perform better in a given game situation. This is the key importance of semiotricity.

So far, there is not much investigation made about semiotricity (Dugas, 2004, 2010; Lemoine, 2003; Martínez de Santos, 2007; Melhli, 2011; Menaut, 1991; Oboeuf, 2010; Oboeuf, Collard , Pruvost, \& Lech, 2009; Parlebas, 1999a, $1999 \mathrm{~b})$, which may be hard to understand if we agree on the foresaid. On their part, Oboeuf et al. (2009) made a research to uncover the so-called "secret code" of football, or the "communication code that serves as a reference to players" (Mombaerts, 1999) analyzing the sociomotor subrole changes and the praxemes envolved. To do this, the authors used observational methodology and created an observational tool ad hoc, explained later on. But there is room enough for some doubts about the reliability of their study because in their paper there is no reference about the observational data quality.

Therefore, the main objective of our research was to check the reliability of this observational tool by means of concordance and generalizability analysis.

\section{Method}

\section{Procedure}

This research used an observational design located in quadrant II (Anguera, Blanco-Villaseñor \& Losada, 2001): punctual, idiographic and multidimensional. The registration procedure was performed using as criteria the non-participation of observers (Anguera, 1992; Anguera \& Hernández-Mendo, 2013; 2014).

The observational units were registered as events because in Oboeuf et al. (2009) paper only the frequency of the events was provided. The data type recorded was multi-event sequences (Bakeman \& Quera, 2011) because the tool was a mixed system of field formats and E/ME category systems. The data recording was continuous (Hernández-Mendo, 1996), so it was vital to plan observational sessions prolonged to do a register without gaps.

The processes to check the reliability of this tool were: (1) thoroughly check of the coding system with the collaboration of a professional football ex-player; (2) development of an observational protocol; (3) rigorous training of observers with the observation protocol (eight sessions two hours long each); (4) data collection: "Obs A1" and "Obs B1" were done at the same day, while the $\mathrm{C}$ group did two observations ("Obs $\mathrm{C} 1$ "and "Obs C2"), each one separated from another by seven days; (5) estimation of coefficients of inter and intraobserver agreements; (6) studies of generalizability of the results.

Unobservability, considered as the time in which the subject, computer or whatever you want to observe can not be observed (Anguera, 1988), was only technological (Hernández-Mendo, 1996; Anguera \& Hernández-Mendo, 2013; 2014). The period of discontinuity appreciated did not exceed the limit of $10 \%$ of it (Anguera 1990), being exactly of 119 seconds in total. The periods with unobservability were not considered in this research.

There are two perspectives to do the data quality control (Anguera, 1992; Hernandez-Mendo, 1996; Anguera, Blanco-Villaseñor, Losada \& Hernández-Mendo, 2000; BlancoVillaseñor \& Anguera, 2003; Blanco-Villaseñor, Castellano, Hernández-Mendo, Sánchez-López, \& Usabiaga, 2014). From a quantitative perspective we evaluated the correlations using the Tau-b coefficients of Kendall, Pearson and Spearman on the frequency table for all multi-event sequences and categories of each criteria obtained by different observers. We also included an index of association, Cohen's Kappa (1960), to assess the effect of random, commission and omission errors calculating the indexes for each category group and for each session. From a qualitative perspective, the consensual agreement, which is used in observational methodology to get an agreement between observers, was the quality control factor (Anguera 1990; Castellano \& Hernández-Mendo 2000; Anguera \& Hernández-Mendo, 2013; Blanco-Villaseñor et al, 2014).

Later on, we applied the generalizability theory (Cronbach, Rajaratnam \& Gleser, 1963; Cronbach, Gleser, Nanda, \& Rajaratnam, 1972) to evaluate the multiple sources of variation in our measurement design (individual, observer, session, days, etc.) and to check that the obtained scores were representative in a wider context (Castellano, 2000). In other words, "to generalize the real observations to any kind of observation to which these belong" (Blanco-Villaseñor, Castellano \& Hernández-Mendo, 2000; Anguera \& HernándezMendo, 2013). This type of analysis can be used with four objectives, but in this work it was only used to determine inter-observer and intra-observer reliabilities. 


\section{Participants}

The coding was performed by two persons, and three observation groups were defined: Observer A, composed of a single observer; Observer B, composed of the other person; and Group C, composed of both observers.

Due to characteristics of the tool and the observation protocol we decided to observe only one player, Sergio Busquets, for 25 minutes during the first part of Netherlands - Spain games of the South Africa 2010 World Cup, which eventually proved to be enough.

\section{Instruments}

The tool we used is a mixed system of field formats and E/ ME category systems, in which the levels of each criterion were systems of mutually exclusive and exhaustive catego- ries themselves. The tool was composed by four criteria: 1) "previous sociomotor subrole" (11 levels), 2) "praxemes and technical actions that indicate subrole change" (18 levels), 3) "final sociomotor subrole" (11 levels), and 4) "moment of subrole change" (3 levels). Each criterion had different categories, but criteria 1 and 3 were composed by the same categories and each multi-event sequence was the logical combination of one level from each criterion.

Every category was defined by a categorical core, which showed the differential content of the category, and by an opening degree, which gave the heterogeneity of behaviors that shared the same categorical core (Gorospe, HernándezMendo, Anguera, \& Martínez Santos, 2005; Anguera \& Hernández-Mendo, 2013; 2014). It was also developed an observation protocol with strategies to register using the tool. For space reasons, we will provide only a small definition of categories that can guide the reader.

Table 1. Categories of criteria 1: "previous sociomotor subrole" (C1) and criteria 3 "final sociomotor subrole" (C3) with different coding systems.

\begin{tabular}{|c|c|}
\hline codes & categorical core \\
\hline $\begin{array}{l}\text { C1 Dribbler (DriP) } \\
\text { C3 Dribbler (DriF) }\end{array}$ & $\begin{array}{l}\text { Offensive sociomotor subrole (OSS) in which the player with the ball tries to dribble one or more opponents who } \\
\text { oppose him directly. }\end{array}$ \\
\hline $\begin{array}{l}\text { C1 Passer (PasP) } \\
\text { C3 Passer (PasF) }\end{array}$ & OSS in which the player with the ball tries to pass it to a teammate. \\
\hline $\begin{array}{l}\text { C1 Receiver (ReceP) } \\
\text { C3 Receiver (ReceF) }\end{array}$ & OSS in which a player not in possession of the ball is preparing to receive it from a teammate. \\
\hline $\begin{array}{l}\text { C1 Shooter (ShoP) } \\
\text { C3 Shooter (ShoF) }\end{array}$ & OSS in which the player with the ball shots on goal trying to score. \\
\hline $\begin{array}{l}\text { C1 Slipper (SliP) } \\
\text { C3 Slipper (SliF) }\end{array}$ & $\begin{array}{l}\text { OSS in which a player not in possession of the ball tries to keep clear from his mark, creating free spaces in the } \\
\text { defense to be used by him or his teammates. }\end{array}$ \\
\hline $\begin{array}{l}\text { C1 Bearer }(\mathrm{BeaP}) \\
\text { C3 Bearer }(\mathrm{BeaF})\end{array}$ & OSS in which a player with the ball moves through free spaces of teammates and opponents. \\
\hline $\begin{array}{l}\text { C1 Tackler (TacP) } \\
\text { C3 Tackler (TacF) }\end{array}$ & $\begin{array}{l}\text { Defensive sociomotor subrole (DSS) in which a player tries to get the ball controlled by an opponent with a } \\
\text { tackle. }\end{array}$ \\
\hline $\begin{array}{l}\text { C1 Interceptor (IntP) } \\
\text { C3 Interceptor (IntF) }\end{array}$ & DSS in which a player tries to intercept a passing or shooting ball to steal or clear it. \\
\hline $\begin{array}{l}\text { C1 Recoverer }(\text { RecoP) } \\
\text { C3 Recoverer }(\text { RecoF })\end{array}$ & $\begin{array}{l}\text { DSS in which a player gets the ball from an opponent receiver, dribbler, or bearer, or regains it after an } \\
\text { opponent's final touch other than a pass. }\end{array}$ \\
\hline $\begin{array}{l}\text { C1 Dissuader (DisP) } \\
\text { C3 Dissuader (DisF) }\end{array}$ & DSS in which a player presses on an opponent bearer or receiver, avoiding his progress. \\
\hline $\begin{array}{l}\text { C1 Recolocater }(\mathrm{RecP}) \\
\text { C3 Recolocater }(\mathrm{RecF})\end{array}$ & $\begin{array}{l}\text { DSS in which a player tries to be in a better position inr elation to his teammates, opponents and ball, in order } \\
\text { to reduce the opponent's free space. }\end{array}$ \\
\hline
\end{tabular}

Table 2. Categories of criteria 2: "praxemes and technical actions that indicate subrole change".

\begin{tabular}{ll}
\hline codes & categorical core \\
\hline Slip (PxSlip) & $\begin{array}{l}\text { Motor action (MA) in which the player, coming from an opponent's back or side of and oriented in relation to } \\
\text { the bearer, trys to generate free space for himself for the next action. }\end{array}$ \\
\hline Ball's call (PxBc) & $\begin{array}{l}\text { MA in which the player anticipates a possible pass making acceleration towards the goal with the intention to } \\
\text { speed up the play andlor winning position. }\end{array}$ \\
\hline
\end{tabular}




\begin{tabular}{|c|c|}
\hline codes & categorical core \\
\hline $\begin{array}{l}\text { Ball's countercall } \\
\text { (PxCount) }\end{array}$ & $\begin{array}{l}\text { MA in which the player does an abrupt acceleration in another direction than the ball's call, which is necessarily } \\
\text { above, with the intention to get free spaces generated by itself to the next motor action. }\end{array}$ \\
\hline Cross run $(\mathrm{PxCr})$ & $\begin{array}{l}\text { MA characterized by a player who crosses by the nearest part of his own goal from one side to another of the } \\
\text { bearer's teammate, and whose intention is to destabilize the opposing defense. }\end{array}$ \\
\hline Supporting run $(\mathrm{PxSr})$ & MA in which the player in front of the bearer makes a run to provide a pass solution. \\
\hline Holding run $(\mathrm{PxHo})$ & MA in which the player behind the bearer makes a run to provide a pass solution. \\
\hline Returning run (PxRr) & $\begin{array}{l}\text { Run of a player who just lost the ball and quickly returns to his defensive position to make the progress of the } \\
\text { adversaries progress more difficult }\end{array}$ \\
\hline Focusing run $(\mathrm{PxFr})$ & Run of a player into the rival bearer or receiver in order to reduce the manoeuvre margin of the opposite team. \\
\hline Tracking run $(\mathrm{Px} T r)$ & Run of a player who follows his direct opponent in order to reduce the manoeuvre margin of the opposite team. \\
\hline Recolocation (PxRe) & $\begin{array}{l}\text { MA characterized by lateral or anterior-posterior movements of the player that trys to be located in a suitable } \\
\text { area according to teammates, opponents and the ball. }\end{array}$ \\
\hline Fixation $(\mathrm{PxFi})$ & $\begin{array}{l}\text { MA characterized by a run oriented to an area defended by two opposing players in order to create a numerical } \\
\text { superiority and facilitate the pass to a teammate in a generated free space. }\end{array}$ \\
\hline Passing feint (PxPf) & $\begin{array}{l}\text { Bearer's MA that makes his opponents believe that he is going to do a pass, while his intention is another one } \\
\text { (dodge, fixate, shot or pass to a teammate). }\end{array}$ \\
\hline Shooting feint (PxSf) & $\begin{array}{l}\text { Bearer's MA that makes his opponents believe that he is going to do a shot while his intention is another one } \\
\text { (dodge, fixate, shoot or pass to a teammate). }\end{array}$ \\
\hline Body feint (PxBf) & Bearer's MA that makes his opponents believe he is going to go on one side while finally going on another. \\
\hline Interception (TaInt) & Action on the ball by the opponent avoiding him from reaching its destination, cutting the pass line or shot. \\
\hline Tackle (TaTac) & Action when the opposing player is in ball possession through a struggle or fight which aims to steal it. \\
\hline Pass (TaPas) & Technical action that transmitting the ball by one tap enables the relationship between two teammates . \\
\hline Shot (TaSh) & All aware shipment to the goal in order to make goal \\
\hline
\end{tabular}

Table 3. Categories of criteria 4 "moment of subrole change"

\begin{tabular}{ll}
\hline Name of categories and coding system. & Definition of the categorical core \\
\hline Played ball $(\mathrm{Pb})$ & Any situation without interruptions. \\
\hline Statutory infraction for the observed team $(\mathrm{SiF})$ & $\begin{array}{l}\text { Is a statutory infraction stipulated by the referee, in favour to the observed } \\
\text { equipment including goal against. }\end{array}$ \\
\hline Statutory infraction against the observed team $(\mathrm{SiA})$ & $\begin{array}{l}\text { Is a statutory infraction stipulated by the referee, against the observed equip- } \\
\text { ment including goal in favour. }\end{array}$ \\
\hline
\end{tabular}

The observation was made on a TV broadcasted game and the software packages we used were Lince1.0 RC16 (Gabín, Camerino, Anguera, \& Castañer, 2012) for coding and data recording, IBM SPSS 20.0.0 for the calculation of the correlation coefficients, GSEQ - SDIS 5.0 (Bakeman \& Quera, 2011) for Cohen's Kappa estimation and EDUG 6.1-e (Cardinet, Johnson, \& Pini, 2010) for the generalizability study.

\section{Results}

The results of the observations done by the three groups are presented below, along with the estimated values for the quality of the recorded data and the probability of their generalizability.

Absolute frequencies of multi-event sequences are shown in Table 4. Table 5 reflects the indexes of multi-event sequences and categorical sequence of the different criteria for interobserver agreement and intraobserver agreement. Cohen's Kappa coefficients for intraobserver and interobserver agreement of sequence of multi-event sequences, as well as the different criteria are shown in Table 6.

Moreover, rates of generalizability analysis were obtained from multi-event sequences. To determine interobserver reliability, a two facets design was applied: categories and observers $(\mathrm{C} / \mathrm{O})$. To determine the intraobserver reliability a two facets design was also applied: categories and observation session $(\mathrm{C} / \mathrm{S})$ for "Obs A1", "Obs C1" and "Obs C2". The relative and absolute coefficients of generalizability are shown in Table 7 and Table 8. 
Table 4. Absolute frequencies of multi-event sequences.

\begin{tabular}{|c|c|c|c|c|}
\hline Multi-event sequences & Frequencies obs A1 & Frequencies obs B1 & Frequencies obs $\mathrm{C} 1$ & Frequencies obs C2 \\
\hline BeaPTaPasPasFPb & 1 & 1 & 1 & 1 \\
\hline DisPPxReSliFPb & 1 & 1 & 1 & 1 \\
\hline DisPPxReRecoFPb & 3 & 3 & 3 & 3 \\
\hline DisPPxReRecoFPb & 1 & 1 & 1 & 1 \\
\hline DisPPxTrDisFPb & 0 & 0 & 0 & 1 \\
\hline DriPTaPasPasFPb & 1 & 1 & 1 & 1 \\
\hline IntPTaPasPasFPb & 3 & 3 & 3 & 3 \\
\hline PasPPxReRecoFPb & 1 & 1 & 1 & 1 \\
\hline PasPPxReSliFPb & 10 & 13 & 12 & 11 \\
\hline PasPPxRrRecoFPb & 1 & 1 & 1 & 1 \\
\hline PasPPxSlipSliFPb & 4 & 2 & 3 & 3 \\
\hline PasPPxSrSliFPb & 1 & 0 & 0 & 1 \\
\hline RecePPxBfDriFPb & 1 & 1 & 1 & 1 \\
\hline RecePPxFi BeaFPb & 1 & 1 & 1 & 1 \\
\hline RecePTaPasPasFPb & 7 & 7 & 7 & 7 \\
\hline RecePTaPasPasFSiF & 1 & 1 & 1 & 1 \\
\hline RecPPxFrDisFPb & 4 & 5 & 4 & 5 \\
\hline RecPPxReRecFPb & 20 & 18 & 21 & 18 \\
\hline RecPPxReRecoFPb & 1 & 1 & 1 & 1 \\
\hline RecPPxReRecoFSiA & 4 & 4 & 4 & 4 \\
\hline RecPPxReSliFPb & 20 & 19 & 20 & 19 \\
\hline RecPPxReSliFSiF & 11 & 11 & 11 & 11 \\
\hline RecPPxRrRecoFPb & 1 & 1 & 1 & 1 \\
\hline RecPTaIntIntFPb & 3 & 3 & 3 & 3 \\
\hline RecPTaTacTacFPb & 1 & 1 & 1 & 1 \\
\hline SliPPxFrDisFPb & 1 & 1 & 1 & 1 \\
\hline SliPPxHoSliFPb & 0 & 1 & 1 & 0 \\
\hline SliPPxReReceFPb & 8 & 7 & 7 & 7 \\
\hline SliPPxReRecFPb & 17 & 15 & 16 & 14 \\
\hline SliPPxReRecoFSiA & 3 & 3 & 3 & 3 \\
\hline SliPPxReSliFPb & 9 & 6 & 7 & 9 \\
\hline SliPPxReSliFSiF & 5 & 5 & 5 & 5 \\
\hline SliPPxRrRecoFPb & 0 & 1 & 0 & 1 \\
\hline SliPPxSlipReceFPb & 2 & 3 & 3 & 3 \\
\hline SliPPxSlipSliFPb & 6 & 7 & 8 & 5 \\
\hline SliPPxSrSliFPb & 2 & 2 & 2 & 2 \\
\hline SliPPxSrSliFSiF & 1 & 1 & 1 & 1 \\
\hline SliPTaPasPasFPb & 1 & 1 & 1 & 1 \\
\hline SliPTaPasPasFSiF & 2 & 2 & 2 & 2 \\
\hline RecoPTaPasPasFPb & 2 & 2 & 2 & 2 \\
\hline TacPPxReRecoFPb & 1 & 1 & 1 & 1 \\
\hline Total & 163 & 158 & 164 & 158 \\
\hline
\end{tabular}


Table 5. Correlation coefficients of multi-event sequences and categories of each criteria for inter and intraobserver agreement.

\begin{tabular}{llcc}
\hline & & Interobserver agreement & Intraobserver agreement \\
\hline \multirow{3}{*}{ Multi-event sequences } & Pearson coefficient & $0.98^{* *}$ & $0.99^{* *}$ \\
& Tau-b coefficient of Kendall & $0.91^{* *}$ & $0.92^{* *}$ \\
& Spearman coefficient & $0.96^{* *}$ & $0.96^{* *}$ \\
& Pearson coefficient & $1.00^{* *}$ & $1.00^{* *}$ \\
Criteria 1 & Tau-b coefficient of Kendall & $1.00^{* *}$ & $1.00^{* *}$ \\
& Spearman coefficient & $1.00^{* *}$ & $1.00^{* *}$ \\
Criteria 2 & Pearson coefficient & $1.00^{* *}$ & $1.00^{* *}$ \\
& Tau-b coefficient of Kendall & $0.95^{* *}$ & $0.90^{* *}$ \\
Criteria 3 & Spearman coefficient & $0.95^{* *}$ & $0.93^{* *}$ \\
& Pearson coefficient & $1.00^{* *}$ & $1.00^{* *}$ \\
& Tau-b coefficient of Kendall & $1.00^{* *}$ & $1.00^{* *}$ \\
Criteria 4 & Spearman coefficient & $1.00^{* *}$ & $1.00^{* *}$ \\
& Pearson coefficient & $1.00^{* *}$ & $1.00^{* *}$ \\
\hline
\end{tabular}

**. Correlation is significant at 0.01 (bilateral)

The correlation coefficients of inter and intraobserver agreements (Table 5) showed high values. Generally speaking, all of the correlation coefficients were very high (over 0.90), especially when the analysis was carried out within each criterion: we found perfect correlations (1.00) except for criteria 2. Lower values were obtained in the multi-event sequences as expected because of the variability generated by the use of four criteria.

Table 6. Cohen's Kappa indexes of multi-event sequences and categories of each criteria for inter and intraobserver agreement.

\begin{tabular}{lcc}
\hline & $\begin{array}{c}\text { Interobs. } \\
\text { agreement }\end{array}$ & $\begin{array}{c}\text { Intraobs. } \\
\text { agreement }\end{array}$ \\
\hline Multi-event sequences & 0.61 & 0.69 \\
Criteria 1 & 0.95 & 0.94 \\
Criteria 2 & 0.86 & 0.82 \\
Criteria 3 & 0.95 & 0.94 \\
Criteria 4 & 0.90 & 0.88 \\
\hline
\end{tabular}

Table 7. Variance analysis and generalization coeficients of interobserver agreement.

\begin{tabular}{lccc}
\hline Source of variance & $\begin{array}{c}\text { Sum of } \\
\text { squares }\end{array}$ & $\begin{array}{c}\text { Degree of } \\
\text { freedom }\end{array}$ & $\begin{array}{c}\text { \% variance } \\
\text { explained }\end{array}$ \\
\hline O & 0.4302 & 1 & 0.0 \\
C & 1983.78563 & 40 & 98.3 \\
OC & 15.63517 & 40 & 1.7 \\
Total & 1999.80488 & 81 & $100 \%$ \\
Relative coef_G & 0.99 & & \\
Absolute coef_G & 0.99 & & \\
\hline
\end{tabular}

Table 8. Variance analysis and generalization coeficients of intraobserver agreement.

\begin{tabular}{lccc}
\hline Source of variance & $\begin{array}{c}\text { Sum of } \\
\text { squares }\end{array}$ & $\begin{array}{c}\text { Degree of } \\
\text { freedom }\end{array}$ & $\begin{array}{c}\text { \% variance } \\
\text { explained }\end{array}$ \\
\hline S & 0.50407 & 2 & 0.0 \\
C & 3052.18467 & 40 & 98.7 \\
SC & 23.98711 & 80 & 1.3 \\
Total & 3076.67585 & 122 & $100 \%$ \\
Relative coef_G & 1.00 & & \\
Absolute coef_G & 1.00 & & \\
\hline
\end{tabular}

The analysis of Cohen's Kappa coefficients showed similar values for inter and intraobserver agreements (Table 6). In the multi-event sequences, the value of interobserver agreement (0.61) was very similar to the value of intraobserver agreement (0.69) and both were lower than those obtained for each criterion alone: 0.86 for criterion 2 ("praxemes and technical actions that indicate subrole change") and 0.95 for criteria 1 ("previous sociomotor subrole") and 3 ("final sociomotor subrole"). The intraobserver agreement they range between 0.82 of criteria 2 "praxemes and technical actions that indicate subrole change" and 0.94 of criteria 1 "previous sociomotor subrole" and 3 "final sociomotor subrole".

In relation to the generalizability of the results, the interobserver reliability analysis revealed that most of the variability $(98.3 \%)$ was associated with the "categories" facet, being null for the "observers" facet and $1.7 \%$ for the (categories/ observers) interaction. The overall analysis of the generalizability coefficients for this design showed that the generaliza- 
tion of results was accurate to a level that can be considered as excellent (0.99). The intraobserver reliability analysis showed similar results. It was also revealed that almost all the variability $(98.7 \%)$ was associated with the "categories" facet, being null for the "observation session" facet, and minor (1.3\%) for the interaction (categories/observation session). The analysis of the generalizability coefficients for this showed that the generalization of results could be considered perfect (1.00).

\section{Discussion}

The importance of this paper lies in the evaluation of an ad hoc tool for the scientific study of semiotricity in football and the practical implications that can be derived from the use of this tool in sports training. None of them is really possible without the necessary statistical validation.

The correlation coefficients of inter and intraobserver agreements (Table 5) are similar to previous researches that have also used this rate to evaluate the reliability of an observational tool (Castellano \& Casamichana, 2009; Castellano, 2000; Castellano \& Hernández-Mendo, 2000; Castellano, Hernández-Mendo, Gómez de Segura, Fontetxa \& Bueno, 2000; Perea, 2008; Perea, Castellano, Hernández-Mendo, Álvarez \& Pérez, 2005; Tapia et al, 2007) and they can be considered optimal.

The analysis of the Cohen's Kappa coefficients showed similar values for inter and intraobserver agreements (Table 6). In the analysis of the interobserver agreement multi-event sequences obtained a lower values than the obtained in similar researches (Arana, Lapresa, Anguera \& Garzón, 2012; Castellano, 2000; Castellano \& Hernández Mendo, 2000; Castellano et al, 2000; Lago \& Anguera, 2003; Losada, 2012; Perea, 2008; Perea et al, 2005), but they can be considered good (Altman, 1991; Fleiss, 1981) or considerable (Landis \& Koch, 1977). The rest of the values obtained for each criterion are in the range of those found in previous researches (Castellano, 2000; Castellano et al, 2000; Perea, 2008; Perea et al, 2005) and can also be considered excellent (Fleiss, 1981), very good (Altman, 1991) or almost perfect (Landis \& Koch, 1977).

The Cohen's Kappa coefficients of intraobserver agreement (Table 6) of multi-event sequences showed lower values than the obtained in similar researches (Arana et al, 2012; Casamichana \& Castellano, 2009; Castellano, 2000; Castellano \& Hernández-Mendo, 2000; Castellano et al, 2000; Lago \& Anguera, 2003; Losada, 2012; Perea, 2008; Perea et al, 2005), although they can be considered good (Altman, 1991; Fleiss, 1981) or considerable (Landis \& Koch, 1977). The remaining values for each one criteria are in the range of previous researches (Casamichana \& Castellano, 2009; Castellano, 2000; Castellano et al, 2000; Perea, 2008; Perea et al, 2005), and they can be considered excellent (Fleiss, 1981), very good (Altman, 1991) or almost perfect (Landis \& Koch, 1977).
As far as the the generalizability of the results is concerned, the inter and intraobserver reliability analysis (Table 7; Table 8) showed excellent results, similar to those obtained in other researches (Castellano, 2000; Castellano et al, 2000; Perea et al, 2005; Tapia et al, 2007), so we can say that inter and intraobserver reliabilities are optimal because observers and observation sessions do not provide variability.

We can affirm that the observation and recording by observers have overcome the data quality control. Correlation coefficients, Cohen's Kappa coefficients and generalizability analysis have provided positive results and confirmed that categories definitions meet the reliability requirements. The lower values obtained when multi-event sequences are employed, due to more omission or commission errors, are still acceptable. Having said so, this interobserver and intraobserver rates of reliability allow us to think that this observation tool is a valid instrument for the study of the communication processes in football and sports alike.

The main difficulties of this research are twofold. Firstly, the lack of scientific production in the semiotricity of sports is evident. Due to this lack of studies that can be used as a reference, we could not optimize certain categories, especially those of criteria 2, "praxemes and technical actions that indicate subrole changen: their definition can be obscure in some cases if you have no experience in observing those motor conducts. Secondly, it has been impossible to have more observers to do the data quality control. With more observers we could have estimated the intra-and interobserver agreements with two groups of two or more observers using the consensus agreement (Anguera, 1990) in both cases and not just in the intraobserver's one.

Even though, there are several lines for future research: optimization of the observational tool that could produce a more detailed knowledge about the interaction processes; new criteria could be added, such as "position player", "part of the game», "game result», "area where subrole change happens ", or «numerical superiority, equality or inferiority»; results from players in different positions could also be analyzed and compared; furthermore, this tool could be used to differentiate the communication processes between footballers of different categories, or with players of the same age but different level; finally, this observational tool could be applied, with appropriate modifications, in team sports with similar internal logic.

\section{Practical applications}

We must highlight the importance of having highly reliable and generalizable observational tools. Previous researches (Hernández-Mendo, 1999; Olmedilla-Zafra, MartínezLozano, Ortín-Montero, 2003) have demonstrated the importance of observation in psychological intervention. This 
observational tool facilitates the psychological interpretation of the actions that players make during the football game. Thus, the knowledge that can be generated with it its can be very useful for coaches and players in trying to improve the tactical knowledge of the game.

\section{References}

1. Altman, D. G. (1991). Practical statistics for medical research. London: Chapman \& Hall.

2. Anguera, M. T. (1988). Observación en la escuela. Barcelona: Graó.

3. Anguera, M. T. (1990). Metodología observacional. In J. Arnau Gras, M. T. Anguera Argilaga, \& J. Gómez Benito (Eds.), Metodología de la investigación en ciencias del comportamiento (Vol. 1, pp. 125-236). Murcia: Secretariado de Publicaciones de la Universidad de Murcia.

4. Anguera, M. T. (1992). Metodología de la observación en ciencias humanas. Madrid: Cátedra.

5. Anguera, M. T., Blanco-Villaseñor, A., \& Losada, J. L. (2001). Diseños observacionales, cuestión clave en el proceso de la Metodología observacional. Metodología de las Ciencias del Comportamiento, 3(2), 135-160.

6. Anguera, M. T., Blanco-Villaseñor, A., Losada, J. L., \& Hernández Mendo, A. (2000). La metodología observacional en el deporte: conceptos básicos. Lecturas: Educación Física y Deportes, 5(24).

7. Anguera, M. T. \& Hernández-Mendo, A. (2013). La metodología observacional en el ámbito del deporte. E-balonmano.com: Revista de Ciencias del Deporte, 9(3), 135-160. http://www.e-balonmano.com/ojs/ index.php/revista/index [Consult: 3 april 2014].

8. Anguera, M. T. \& Hernández-Mendo, A. (2014). Metodología observacional y psicología del deporte: Estado de la cuestión. Revista de Psicología del Deporte, 23(1), 13-109.

9. Arana, J. (2011). Adaptando el fútbol al niño de 12-13 años: análisis observacional de la utilización del espacio en las modalidades de fútbol 7 , fútbol 9 y fútbol 11. (Dissertation). Universidad de La Rioja. Logrońo.

10. Arana, J., Lapresa, D., Anguera, M. T., \& Garzón, B. (2012). Adapting football to the child: an application of the logistic regression model in observational methodology. Quality \& Quantity, 44(1), 1-8.

11. Ardá, A. (1998). Análisis de patrones en futbol a 7. Estudio de las acciones ofensivas. (Dissertation). Universidad de La Coruña. Logrońo.

12. Bakeman, R., \& Quera, V. (2011). Sequential analysis and observational methods for the behavioral sciences. Cambridge, UK: Cambridge University Press. ISBN: 9781101001244 (hdcv), 9780521171816.

13. Bayer, C. (1986). La enseñanza de los juegos colectivos deportivos. Barcelona. Hispano-Europea.

14. Blanco-Villaseñor, A., Castellano, J., \& Hernández-Mendo, A. (2000). Generalizabilidad de las observaciones de la acción del juego en el fútbol. Psicothema, 12(Supplement), 81-86.

15. Blanco-Villaseñor, A., Castellano, J., Hernández-Mendo, A., SánchezLópez, C.R., \& Usabiaga, O. (2014). Aplicación de la TG en el deporte para el estudio de la fiabilidad, validez y estimación de la muestra. Revista de Psicología del Deporte, 23(1), 131-137.

16. Cardinet, J., Johnson, S., \& Pini, G. (2010). Applying generalizability theory using EduG. New York: Routledge Academic.

17. Casamichana, D., \& Castellano, J. (2009). Análisis de los diferentes espacios individuales de interacción y los efectos en las conductas motrices de los jugadores: aplicaciones al entrenamiento en fútbol. Motricidad: revista de ciencias de la actividad fisica y del deporte, (23), 143-167.

18. Castellano, J. (2000). Observación y análisis de la acción de juego en el fútbol. (Dissertation). Universidad del País Vasco - Euskal Herriko Unibertsitatea. Vitoria-Gasteiz.

19. Castellano, J. \& Echeazarra, I. (2013). Adapting model competition in youth football: a comparative study of 5-a side football and 7-a side football in U-9 players. In H. Nunome, B. Drust y D. Dawson (Ed.), Science and football VII (pp. 311-316). London: Routledge.

20. Castellano, J., \& Hernández-Mendo, A. (2000). Análisis secuencial en el fútbol de rendimiento. Psicothema, 12(2), 117-121.

21. Castellano, J., Hernández-Mendo, A., Gómez de Segura, P., Fontetxa, E., \& Bueno, I. (2000). Sistema de codificación y análisis de la calidad del dato en el fútbol de rendimiento. Psicothema, 12(4), 635-641.

22. Castellano, J., Hernández-Mendo, A., Morales-Sánchez, V. y Anguera, M. T. (2007). Optimising a probabilistic model of the development of play in soccer. Quality \& Quantity, 41(1), 93-104.

23. Castelo, J. F. F. (1994). Fútebol. Modelo técnico-táctico do jogo. Lisboa: Ediçoes FMH.

24. Cohen, J. (1960). A coefficient of agreement for nominal scales. Educational and psychological measurement, 20(1), 37-46.

25. Cronbach, L. J., Gleser, G. C., Nanda, H., \& Rajaratnam, N. (1972). The dependability of behavioral measurements: Theory of generalizability for scores and profiles. New York: John Wiley \& Sons.

26. Cronbach, L. J., Rajaratnam, N., \& Gleser, G. C. (1963). Theory of generalizability: a liberalization of reliability theory. British Journal of Mathematical and Statistical Psychology, 16(2), 137-163. doi/10.1111/j.2044-8317.1963.tb00206.x/abstract

27. Dugas, É. (2004). Corps agissant et corps communicant au sein des jeux sportifs. In A. Giordan, J. L. Martinand \& D. Raichvarg (Éds.), Le corps objet scientifique, objet technologique dans l'éducation et la culture, Actes des XXVIes Journées internationales sur la communication, l'éducation et la culture scientifiques, techniques et industrielles, (6 pages). Paris: DIRES.

28. Fleiss, J. L. (1981). Statistical methods for rates and proportions. New York: John Wiley and Sons.

29. Gabín, B., Camerino, O., Anguera, Ma.T. \& Castañer, M. (2012). Lince: multiplatform sport analysis software. Procedia-Social and Behavioral Sciences, 46, 4692-4694.

30. Gorospe, G., Hernández-Mendo, A., Anguera, M. T., \& Martínez De Santos, R. (2005). Desarrollo y optimización de una herramienta observacional en el tenis de individuales. Psicothema, 17(1), 123-127.

31. Gréhaigne, J. F. (2001). La organización del juego en el fútbol. Barcelona: Inde.

32. Hernández-Mendo, A. (1996). Observación y análisis de patrones de juego en deportes sociomotores. (Unpublished dissertation). Universidade de Santiago de Compostela. Santiago de Compostela.

33. Hernández-Mendo, A. (1999) Observación y deporte. In M. T. Anguera (Coord), Observación en deporte y conducta cinésico-motriz: Aplicaciones (pp. 39-70). Barcelona: Edicions de la Universitat de Barcelona.

34. Konzag, I. (1983). La formazione tecnico-tattica nei giochi sportivi. Revista di Cultura Sportiva, 11(2), 42-47.

35. Lago, J. (2011). Influencia de los condicionantes estratégicos y las variables situacionales en el rendimiento de la fase ofensiva en fútbol. (Dissertation). Universidad de Vigo, Pontevedra.

36. Lago, C., \& Anguera, M. T. (2003). Utilización del análisis secuencial en el estudio de las interacciones entre jugadores en el fútbol de rendimiento. Revista de Psicología del Deporte, 12(1), 27-37.

37. Landis, J. R., \& Koch, G. G. (1977). The measurement of observer agreement for categorical data. Biometrics, 159-174.

38. Lemoine, A. (2003). Étude de la production d'information dans le cadre de la transmission instantanée du ballon au football. (Unpublished doc- 
toral dissertation). Université de Picardie Jules Verne. Amiens.

39. Losada, J. L. (2012). Relacion entre zonas y contextos de interaccion en el fútbol de alto rendimiento: una aplicacion multivariante. Motricidad. European Journal of Human Movement, 28, 171-183.

40. Martínez de Santos, R. (2007). La praxiología motriz aplicada al fútbol. (Dissertation). Universidad del País Vasco - Euskal Herriko Unibertsitatea. Vitoria-Gasteiz.

41. Martínez de Santos, R. (2008). Ser y parecer en los juegos deportivos. Una introducción a la semiotricidad. [V Congreso de la Asociación Española de Ciencias del Deporte, León 23-25 de octubre]. Asociación Española de Ciencias del Deporte.

42. Melhli, N. (2011). L'espace entre les joeuers de football comme une signe lisible et communicatif du type cognitif du joueur. (Dissertation). Université de Bordeaux. Bourdeaux.

43. Menaut, A. (1992). Estructuras cognoscitivas y lógica de la acción de juego. Kirola Ikertuz, 5, 25-45.

44. Mombaerts, E. (1999). Pédagogie du football: Apprendre à jouer ensemble par la pratique du jeu. Paris: Vigot.

45. Mombaerts, E. (2000). Fútbol: del análisis del juego a la formación del jugador. Barcelona: Inde.

46. Oboeuf, A. (2010). Sport, communication et socialisation. Paris: Éditions des archives contemporaines.

47. Obœuf, A., Collard, L., Pruvost, A., \& Lech, A. (2009). La prévisibilité au service de l' imprévisibilité. Réseaux, 146(4), 1-26.

48. Olmedilla-Zafra, A., Lozano-Martínez, F. J. \& Ortín-Montero, F. J. (2003). La utilización de registros para la mejora del comportamiento táctico en deportes de equipo. Revista de Psicología del Deporte, 12 (1), 95-106.

49. Parlebas, P. (1976). Activités physiques et éducation motrice. Paris: Revue EPS.

50. Parlebas, P. (1999a). Une dynamique novatrice. In P. Parlebas (Ed.), Le corps et le langage: parcours accidentés. Paris: Editions L'Harmattan.

51. Parlebas, P. (1999b). Les tactiques du corps. In M. P. Julien \& J. P.
Warnier (Eds.), Approches de la culture matérielle-corps à corps avec l'objet (pp. 29-43). Paris: L'Harmattan.

52. Parlebas, P. (2001). Léxico de praxiología motriz. Juegos, deportes y sociedades. Barcelona: Paidotribo.

53. Parlebas P., \& Dugas E. (1998). Transfert d'apprentissage et domaines d'action motrice [Transfer of learning and motor action domains]. Education Physique et Sportive, 270, 41-47.

54. Perea, A. (2008). Análisis de las acciones colectivas en el fútbol de rendimiento. (Dissertation). Universidad del País Vasco - Euskal Herriko Unibertsitatea. Vitoria-Gasteiz.

55. Perea, A., Castellano, J., Hernandez-Mendo, A., Álvarez, D., \& Pérez, L. (2005). Pautas para el análisis de la calidad del dato en la observación de los deportes colectivos: una aplicación en el fútbol. [I Congreso Virtual de Investigación en la Actividad Física y el Deporte, Vitoria-Gasteiz, septiembre]. IVEF-SHEE de Vitoria-Gasteiz.

56. Reina, A. (2011). Evaluación de factores implicados en el rendimiento del fútbol profesional. (Dissertation). Universidad de Málaga, Málaga.

57. Robles, F. J. (2012). Observación y análisis de las acciones ofensivas de la selección española de fútbol en la Eurocopa de 2008 y en el Mundial de 2010. (Unpublished dissertation). Universidad del País Vasco - Euskal Herriko Unibertsitatea. Vitoria-Gasteiz.

58. Sampedro, J. (1996). Análisis praxiológico de los deportes de equipo: una aplicación al fútbolsala. (Dissertation). Universidad Politécnica de Madrid. Madrid.

59. Sternberg, R., \& Barry, S. (2011). The Cambridge Handbook of Intelligence. New York: Cambridge University Press

60. Tapia, A., Reina, Á., Díaz, F., Berrocal, M. Á., García, J. A., Gálvez, P., \& Hernández Mendo, A. (2007). Observación de las acciones ofensivas en un equipo de fútbol. Lecturas: Educación física y deportes, (108), 45. http://www.efdeportes.com/efd148/futbol-concepto-e-investigacion.htm [Consult: 24 april 2014].

61. Teodorescu, L. (1984). Problemas de teoria e metodologia nos jogos desportivos. Lisboa: Livros Horizonte. 